\title{
IMPORTANCE OF GUT MICROBIOTA IN FISH - A REVIEW
}

\begin{abstract}
A. UMA ${ }^{1 *}$, P. SUBASH${ }^{1}$ AND T. J. ABRAHAM ${ }^{2}$
${ }^{1}$ Department of Aquatic Animal Health Management, Dr. M.G.R. Fisheries College and Research Institute, Tamil Nadu Dr. J. Jayalalitha Fisheries University, Ponneri - 601 204, Tamil Nadu, India

${ }^{2}$ Department of Aquatic Animal Health, West Bengal University of Animal and Fishery Sciences, Chakgaria, Kolkata -700 094, West Bengal, India

The microbiota are normally involved in numerous factors concerned with the health of the fishes in their environment and many of them can also cause threats to the same. In fish, the gut microbiota inhabiting the gastrointestinal tract influence the physiology, nutrition, life span, immunity, besides acting as a barrier against pathogens. Although gut microbiotas are present in all the fish, their composition varies based on their life stages, the environment in which they live, diet, seasons, trophic levels, etc. There are numerous studies related to the intestinal microbiota of freshwater, marine fish and in various life stages of fish. But the knowledge on the microbiota in aquatic ecosystem is yet to be explored. Researches in this field will pave way to the develop techniques to manipulate the gut microbiota of the desired fish species of culture to improve their growth and production. This review is intended to provide collective information on the gut microbiota in fish, their development, dynamics in the living environment and their manipulation towards improving production and sustainability in the field of fisheries.
\end{abstract}

Key words: Freshwater fish, Gut microbiota, Manipulation of gut microbiota, Marine fish

\section{Introduction}

Fishes are poikilothermic aquatic animals that consist of a vast range of vertebrates to invertebrates of the animal kingdom. Fish are considered as sources of low-fat high-quality protein; rich in omega-3 fatty acids, vitamins like $\mathrm{B}_{2}$ and $\mathrm{D}$ and minerals such as iron, calcium, phosphorus, iodine, magnesium, zinc and potassium. The consumption of fish has been increased by increasing the world's population from the mid of the $20^{\text {th }}$ century. According to FAO (2020), in per capita terms, there is increase of fish consumption from $9.0 \mathrm{~kg}$ in 1961 to $20.2 \mathrm{~kg}$ in 2015 , at an average rate of $1.5 \%$ increase per year. The estimate for 2016 and 2017 was about 20.3 and $20.5 \mathrm{~kg}$ respectively. Such demand was contributed by the total global fish production of 170.9 MMT through 90.9 MMT of capture fisheries and 80.0 MMT of aquaculture. The aquaculture sector, contributed by both inland and marine sector produced 51.4 MMT and 28.7 MMT, respectively contributing up to $46.8 \%$ of total fish production.

Fish possess bacterial flora on or in their skin and its various organs (Austin, 2002). Generally, the bacterial genera isolated are related to the environment of the fish and varies with numerous factors such as the salinity and the load of bacterial communities in the water. The bacteria recovered from the surface of skin and gills may be temporary rather than resident on the surface of the fish. Gut microbiota of fish appear to vary with the complications in the digestive system. The microbiota present in the gut is the representation 
of those from the surrounding environment or the diet fed which can survive and multiply within intestinal tract, there is also evidence for a different intestinal microflora in some species (Cahill, 1990). Gut microbiota can influence development, life span, physiology, immunity, and barriers against the pathogen in fish (Yan et al., 2016). Hence, the components that direct the intrusion of microbes in the fish gut will give an underlying advance towards anticipating and treating fish diseases (Xiong et al., 2019).

Several factors may affect the microbiota of the fish gut. The changes in external factors like age, diet, environment and trophic levels can alter the gut microbiota of the fish (Liu et al., 2016; Stephens et al., 2016; Michl et al., 2017; Wang et al., 2018). To study the gut microbiomes in fish, various methods are being adopted for the examination of the confederation of microorganisms. In the past, the culturedependent methods (Ringo et al., 2003; Romero and Navarrete, 2006), denaturing gradient gel electrophoresis and temporal temperature gradient gel electrophoresis techniques (Reveco et al., 2014) revealed a very low fraction of the significant microorganisms. But, today there are wide varieties of culture-independent technique available for the analysis of microbiota of fish (Tarnecki et al., 2017). By knowing the importance of microbial communities in the fish body, we can manipulate these communities to bring out the best possible role to be expressed in their body for the benefit of fish health.

\section{Historical overview of gut microbiota of fish}

The collective genomes within the microorganisms inhabiting a particular environment were termed as a microbiome (Burokas et al., 2015). Higher vertebrates harbour these microbial communities in their body from the skin surface to the gastrointestinal tract (Sandrini et al., 2015). The studies on such a complex form of microorganisms in fishes started as early as the 1930s (Reed and Spence, 1929; Gibbons, 1933) in which they investigated the skin and gut microbial communities. The study was further explored by the influence of intestinal flora in fish on fasting (Margolis, 1953). Understanding the importance of these microbiomes has led to several studies in fish viz. changes in the gut microbiota with response to the diet (Sera et al., 1972), variation in the gut microbiota of the farmed fish (Gilmour et al., 1976), the influence of the gut microbiome by the surrounding environment and the intake of diet (Cahill, 1990). One of the limitations in the isolation and culture of gut microbiota using culture-dependent methods is that, only $10 \%$ of microorganisms has been studied.

\section{Gut microbiota of freshwater fish}

Considerable differences in the composition of intestinal microbial flora in marine and freshwater fish are described by Izvekova et al. (2007). The gut microbial composition of the freshwater fish differs due to the varying environmental conditions of their habitat. Acinetobacter, Aeromonas, Flavobacterium, Lactococcus, Pseudomonas, obligate anaerobes (Bacteroides, Clostridium and Fusobacterium) and members of family Enterobacteriaceae dominate the gut of freshwater species (Gómez and Balcazar, 2008). A limited number of bacterial taxa found in the intestines of some fish species may indicate not only a low diversity of these bacteria but may also be due to insufficient knowledge about them. Herbivorous and omnivorous freshwater fish shows shorter gut transit times with low levels of short chained fatty acids (SCFA) in the gut, which are produced during the conversion of unassimilable algal constituents by the gut microbes (German et al., 2010) than some of their marine counterparts. The highest level of SCFA was reported in the posterior intestine of Oreochromis sp. Free living Amoebae are ubiquitous in freshwater fish Oreochromis niloticus (Milanez et al., 2017) and its infection poses a public health problems due to possible human consumption. Beneficial gut microbiota reported in various freshwater fish are presented in Table. 1 
Table 1. Beneficial gut microbiota reported in various freshwater fish

\begin{tabular}{|c|c|c|}
\hline Host & Dominant gut microbiota & Reference \\
\hline $\begin{array}{l}\text { Nile tilapia Tilapia nilotica, goldfish } \\
\text { (Carassius auratus), and Ayu } \\
\text { (Plecoglossus altivelis) }\end{array}$ & $\begin{array}{l}\text { Obligate anaerobes (Bacteroidaceae) } \\
\text { were predominant over facultative } \\
\text { anaerobes (Vibrionaceae and } \\
\text { Enterobacteriaceae) }\end{array}$ & $\begin{array}{l}\text { Sakata } \\
\text { et al., } 1980\end{array}$ \\
\hline $\begin{array}{l}\text { Japanese eel (Anguilla japonica), } \\
\text { carp (Cyprinus carpio), goldfish } \\
\text { (Carassius auratus), Ayu } \\
\text { (Plecoglossus altivelis), tilapia } \\
\text { (Tilapia nilotica) and channel catfish } \\
\text { (Ictalurus punctatus) }\end{array}$ & $\begin{array}{l}\text { Bacteroides type } \mathrm{A} \text {, with the potential } \\
\text { of producing vitamin } \mathrm{B}_{12}\end{array}$ & $\begin{array}{l}\text { Sugita } \\
\text { et al., } 1991\end{array}$ \\
\hline $\begin{array}{l}\text { Ayu (Plecoglossus altivelis), carp } \\
\text { (Cyprinus carpio), channel catfish } \\
\text { (Ictalurus punctatus), Japanese eel } \\
\text { (Anguilla japonica) and Tilapia } \\
\text { (Tilapia nilotica) } \\
\end{array}$ & $\begin{array}{l}\text { Aeromonas, Bacteroidaceae } \\
\text { and Clostridium strains producing } \\
\text { amylase that play an important role in } \\
\text { the digestion of starch }\end{array}$ & $\begin{array}{l}\text { Sugita et al., } \\
1997\end{array}$ \\
\hline $\begin{array}{l}\text { Silver carp (Hypophthalmichthys } \\
\text { molitrix), common carp (Cyprinus } \\
\text { carpio), channel catfish (Ictalurus } \\
\text { punctatus) and deepbodied crucian } \\
\text { carp (Carassius cuvieri) }\end{array}$ & $\begin{array}{l}\text { Lactococcus raffinolactis, a } \\
\text { predominant intestinal LAB }\end{array}$ & $\begin{array}{l}\text { Hagi et al., } \\
2004\end{array}$ \\
\hline $\begin{array}{l}\text { Goldfish (Carassius auratus), common } \\
\text { carp (Cyprinus carpio) and Mozambique } \\
\text { tilapia (Oreochromis mossambicus) }\end{array}$ & $\begin{array}{l}\text { Bacteroides type A strains with high } \\
\text { vitamin } \mathrm{B}_{12} \text { producing ability, } \\
\text { Vancomycin-resistant bacteria such } \\
\text { as Cetobacterium somerae }\end{array}$ & $\begin{array}{l}\text { Tsuchiya } \\
\text { et al., } 2008\end{array}$ \\
\hline $\begin{array}{l}\text { Rohu (Labeo rohita) and catla (Catla } \\
\text { catla) }\end{array}$ & $\begin{array}{l}\text { Lactic acid bacteria Enterococcus } \\
\text { faecalis and Pediococcus acidilactici } \\
\text { to ferment fish processing waste }\end{array}$ & $\begin{array}{l}\text { Rai et al., } \\
2011\end{array}$ \\
\hline Zebrafish (Danio rerio) & $\begin{array}{l}\text { Aeromonas spp., Pseudomonas spp., } \\
\text { Plesiomonas spp., Vibrio spp., } \\
\text { Shewanella spp. and Cetobacterium } \\
\text { spp. }\end{array}$ & $\begin{array}{l}\text { Roeselers } \\
\text { et al., } 2011\end{array}$ \\
\hline $\begin{array}{l}\text { Rohu (Labeo rohita), Mrigal (Cyrrhinus } \\
\text { mirgala) and Tilapia (Oreochromis } \\
\text { mossambicus) }\end{array}$ & $\begin{array}{l}\text { Enterobacter asbura, Pichia } \\
\text { kudriavzevii, Candida tropicalis and } \\
\text { Candida parapsilosis can produce } \\
\text { tannase to overcome the } \\
\text { antinutritional factors in the } \\
\text { feedstuffs. }\end{array}$ & $\begin{array}{l}\text { Mandal and } \\
\text { Ghosh, } \\
2013\end{array}$ \\
\hline $\begin{array}{l}\text { Channel catfish (Ictalurus punctatus), } \\
\text { Largemouth bass (Micropterus } \\
\text { salmoides) and Bluegill (Lepomis } \\
\text { macrochirus) }\end{array}$ & $\begin{array}{l}\text { Cetobacterium somerae, } \\
\text { Plesiomonas shigelloides, } \\
\text { Fusobacterium mortiferum } \\
\text { and Aeromonas sp. }\end{array}$ & $\begin{array}{l}\text { Larsen } \\
\text { et al., } 2014\end{array}$ \\
\hline
\end{tabular}


Cont. Table 1 .

Indian Journal of Animal Health, Special Issue, December, 2020

\begin{tabular}{lll}
\hline \multicolumn{1}{c}{ Host } & Dominant gut microbiota & Reference \\
\hline $\begin{array}{l}\text { Mrigal (Cyrrhinus mirgala and Tilapia } \\
\text { (Oreochromis niloticus) }\end{array}$ & $\begin{array}{l}\text { Pichia kudriavzevii and Candida } \\
\text { rugosa, extracellular enzyme } \\
\text { producing yeasts }\end{array}$ & $\begin{array}{l}\text { Banerjee } \\
\text { and Ghosh, } \\
2014\end{array}$ \\
\hline $\begin{array}{l}\text { Freshwater fishes Schizothorax zarudnyi } \\
\text { and Schizocypris altidorsalis }\end{array}$ & $\begin{array}{l}\text { Actinobacteria with their potential } \\
\text { to produce biologically active } \\
\text { compounds. }\end{array}$ & $\begin{array}{l}\text { Jami } \text { et al., } \\
2015\end{array}$ \\
\hline Grass carp (Ctenopharyngodon idellus) & $\begin{array}{l}\text { Dechloromonas, Methylocaldum, } \\
\text { Planctomyces, } \text { Rhodobacter, }\end{array}$ & Tran et al., \\
& $\begin{array}{l}\text { Caulobacter, Flavobacterium, } \\
\text { and Pseudomonas }\end{array}$ & \\
& $\begin{array}{l}\text { Gammaproteobacteria, } \\
\text { Fosobacteria, Actinobacteria, } \\
\text { Freshwater pufferfish (Tetraodon } \\
\text { cutcutia) }\end{array}$ & Debolineae, Betaproteobacteria,, \\
& $\begin{array}{l}\text { Deinococci, Clostridia and } \\
\text { Deltaproteobacteria }\end{array}$ & \\
& & \\
\hline
\end{tabular}

\section{Gut microbiota of marine fishes}

The fish and other marine animals have their unique interaction with the surrounding environment and the microorganisms inhabiting the environment. The gut of marine fish is dominated by Alcaligenes, Alteromonas, Aeromonas, Flavobacterium, Carnobacterium, Moraxella, Micrococcus, Pseudomonas and Vibrio (Gómez and Balcazar, 2008). A summary of the major bacterial flora composing the gut microbiota of marine fish was reviewed by Llewellyn et al. (2014). A review of the intestinal microflora of fish larvae and fry of 24 marine and freshwater fish showed the most frequently reported bacteria were Vibrio, Pseudomonas, Cytophaga, Flavobacterium and the family Enterobacteriaceae (Ring $\varnothing$ and Birkbeck, 1999). While the microbial community changes with life stage and habitat, a relatively stable gut microbiota are established within the first 50 days of life for many species (Larsen et al., 2014). Lactic acid bacteria (mainly Lactobacillus sp.) have also been found to be minor components of the gut microflora of both freshwater and marine fish (Izvekova et al., 2007). Table 2 shows the dominant gut microbial communities in marine fish.

\section{Importance of gut microbiomta in disease resistance}

Gut microbiota are the microorganisms that are colonizing the digestive tract, enveloping the entire scope of the biochemical cycle, and incite a resistant arrangement of the host life form (Gómez and Balcazar, 2008). Numerous beneficial bacterial strains have been created to treat microorganism prompted bacterial maladies, and this current strategy's adequacy has been demonstrated (Verschuere et al., 2000). Some beneficial microbes can create microorganisms that stifle or even destroy the inhibitory compounds (Teplitski et al., 2009). Lactococcus lactis isolated from marine fish produced bacteriocin nisin $\mathrm{Z}$, which can restrain the development of the fish microbe Lactococcus garvieae at $5 \mathrm{AU} \mathrm{mL}^{-1}$ made it a promising option in the prevention of lactococcosis (Sequeiros et al., 2015). A bacteria Centroscyllium fabricii isolated from the deep sea shark was found to have an antagonistic activity in the fish gut (Bindiya et al., 2015).

\section{Gut microbiota with respect to the life stages in fish}

The colonization of fish gut begins early in the 
Table 2. Dominant gut microbial communities in marine fish

\begin{tabular}{|c|c|c|}
\hline Host & Dominant gut microbiota & Reference \\
\hline Neritic sharks & Photobacterium damselae & Grimes et al.,1985 \\
\hline $\begin{array}{l}\text { Atlantic salmon (Salmo salar), Long } \\
\text { jawed mudsucker (Gillichythys mirabilis) }\end{array}$ & Tenericutes (Mycoplasma sp.) & $\begin{array}{l}\text { Bano et al., 2007; } \\
\text { Llewellyn et al., } \\
2016\end{array}$ \\
\hline Penaeus monodon & Gamma Proteobacteria & $\begin{array}{l}\text { Rungrassamee } \\
\text { et al., 2014, } 2016\end{array}$ \\
\hline $\begin{array}{l}\text { Pacific white shrimp (Penaeus } \\
\text { vannamei) }\end{array}$ & Gamma Proteobacteria & $\begin{array}{l}\text { Rungrassamee } \\
\text { et al., } 2016\end{array}$ \\
\hline 12 bony fish and 3 sharks & Proteobacteria, Firmicutes & Givens et al., 2015 \\
\hline $\begin{array}{l}\text { Damselfish (Pomacentridae) and } \\
\text { Cardinalfish (Apogonidae) }\end{array}$ & $\begin{array}{l}\text { Endozoicomonaceae, } \\
\text { Shewanellaceae, Fusobacteriaceae, } \\
\text { Vibrionaceae and Pasteurellaceae }\end{array}$ & Parris et al., 2016 \\
\hline$\overline{\text { Rabbitfish (Siganus muscescens) }}$ & $\begin{array}{l}\text { Firmicutes, Bacteroidetes and } \\
\text { delta-Proteobacteria }\end{array}$ & Nielsen et al., 2017 \\
\hline $\begin{array}{l}\text { Pacific white shrimp (Penaeus } \\
\text { vannamei) }\end{array}$ & $\begin{array}{l}\text { Alpha Proteobacteria alongside } \\
\text { Planctomycetales }\end{array}$ & Chen et al., 2017 \\
\hline Atlantic cod (Gadus morhua) & $\begin{array}{l}\text { Firmicutes, Proteobacteria, } \\
\text { Bacteroidetes, and Fusobacteria can } \\
\text { act as biomarker for oil contamination }\end{array}$ & Walter et al., 2019 \\
\hline $\begin{array}{l}\text { Dicentrarchus labrax, Sparus aurata, } \\
\text { Diploduspuntazzo, Pagruspagrus, } \\
\text { Argyrosomus regius }\end{array}$ & $\begin{array}{l}\text { Pelomonas puraquae, } \\
\text { Hydrogenophaga atypica, } \\
\text { Atopostipes suicloacalis, } \\
\text { Pseudomonas veronii, } \\
\text { Propionibacterium (Cutibacterium } \\
\text { acnes, Pseudomonas panacis and } \\
\text { Delftia acidovorans) }\end{array}$ & Nikouli et al., 2020 \\
\hline
\end{tabular}

larval stage and is driven towards the achievement of a complex assemblage of gutassociated microorganisms (Nayak, 2010). Microbial colonisation of fish larvae originates from the eggs, the environment and the first feed. The microbiota of the surrounding water dictates which bacteria encounter the eggs and consequently have the opportunities to colonise. Upon hatching, sterile larvae intake the chorion-associated bacteria, which are the first colonisers of the developing gastrointestinal tract (GIT) (Egerton et al., 2018). The GIT of the newly hatched larvae tends to contain a few bacteria. Subsequent bacterial habitats are acquired in the fish larvae for the first time when they begin to drink water to control osmoregulation and the microbiota then becomes further diversified through feeding
(Hansen and Olafsen, 1999). Numerous studies have shown that diet plays a major role in shaping the gut microbial community and from first feeding; cause to substantial diversification (Lauzon et al., 2010). Around $10^{8}$ bacterial cells having a place with more than 500 distinct species are accounted to populate the fish gut, which is overwhelmed by aerobes or facultative anaerobes (Romero and Navarrete, 2006). The diversity of the gut microbiota generally increases as the fish diet changes from predatory to omnivorous and omnivorous to herbivorous (Liu et al., 2016). The gut colonization can be either driven by stochastic (neutral assembly) or deterministic (non- neutral model). Stochastic deduced from random dispersion of microorganisms or events that land 
the microorganisms into the intestine that are responsible for the final shape of the gut microbial community and in deterministic, the assembly is acquired by the host selective factors, active dispersal by the host and microbe and microbe-microbe interactions (Talwar et al., 2018). Over a formative time, the colonization of gut was started by seeding from the surrounding environment, then progressively determined by the non-neutral factors as the fish matures from larvae to adult (Yan et al., 2016). Therefore, the studies suggested stochastic factors as a determinant in colonization of the GI tract. The gut microbial community can change with a variety of factors affecting the host, including changing environmental conditions such as temperature and salinity (Macfarlane and Englyst, 1986), developmental stage (Romero and Navarrete, 2006), digestive physiology (Cahill, 1990) and feeding strategy (Uchii et al., 2006). Some of the gut microfloras appear to be temporary, while other bacterial floras seem to be permanent residents (Kim et al., 2007). Herbivorous fish like pinfish Lagodon rhomboides under-goes an ontogenetic diet shift, while transitioning from carnivorous juveniles to either omnivorous or herbivorous adults (Gallagher et al., 2001).

Likewise, the growth, development and migration in anadromous Atlantic salmon Salmo salar involve a radical shift across an ecological and trophic spectrum (Orlov et al., 2006). Accompanying the behavioural, physiological and dietary adaptations are necessary to cope up with the transition between freshwater and marine environments (McCormick et al., 2013). The ecological succession of gut microbial communities during development and migration of wild teleost is an excellent system to explore the contribution of host and environmental factors in shaping the microbiome recruitment, particularly in euryhaline species (Schmidt et al., 2015). The study of Xia et al. (2014) provided the first perception into the fish gut microbiota and its changes during starvation. A detailed study on interactions between gut microbiota and hosts under such dynamic conditions will through new light on how the hosts and microbes respond to the dynamic environment. Nikouli et al. (2020) provided evidence on adult farmed fish in the Mediterranean sea have a divergent and speciesspecific gut microbiota profile, that are shaped independently of the similar environmental conditions under which they grow.

Herbivorous marine fish species having higher intestinal short-chain fatty acid concentrations depend on the intestinal microbiota to convert the unassimilable algal constituents to metabolically useful short-chain fatty acids (White et al., 2010), and these fish displays metabolic specializations to the hindgut fermentation (Willmott et al., 2005). Absorption of such short-chain fatty acid in fish is driven by an osmotic gradient between the intestine and blood (Titus and Ahearn, 1992), and so the concentration of these end products of anaerobic metabolism of microbiome in the posterior gut can serve as a rough indicator on potential importance of microbial digestion. Proteobacteria has far and wide presence in the gut microbiota of the aquatic invertebrates and are dominant in crustacean gut (Rungrassamee, 2014; Holt et al., 2020). The phylum proteobacterium is highly diverse in genetics, morphology and physiology (Stackebrandt et al., 1988). Crustaceans predominantly consist of Vibrio and Photobacterium spp. which have additionally classified sequences attributed to other high-level taxa: Bacteroidetes, Firmicutes, Fusobacteria and Actinobacteria in Penaeus monodon (Rungrassamee et al., 2014). Numerous Vibrio spp. produce chitinolytic enzymes (Sugita and Ito, 2006), which may express their strength in a chitin-rich environment like crustacean gut by giving a niche substrate for their use. However, the enzymatic capability of a few Vibrio spp. may contribute to negative impacts on the carapace of the animals and other health 
implications such as red disease, tail necrosis, loose shell syndrome (Jayasree et al., 2006). Microbial profiles are likely impacted by the longitudinal axis of the gut itself as various morphologies and functions along the gut will induce differential pressures on the microbial selection (Holt et al., 2020). These interior variations show comparable taxa in the gut of wild and farmed $P$. monodon (Rungrassamee et al., 2014). Penaeus vannamei guts from various farms were more likely similar to each other despite differences in the microbial community structure of their respective rearing environment (Zoqratt et al., 2018). Table 3 provides the details of the factors that are affecting the microbial communities in fish.

Table 3. Factors that are affecting the microbial communities in fish

\begin{tabular}{|c|c|c|}
\hline Factors & Findings & Reference \\
\hline \multirow[t]{2}{*}{ Age } & Microbial diversity increases with host-age. & Wang et al., 2018 \\
\hline & $\begin{array}{l}\text { Age has a significant influence on the intestinal microbiota; } \\
\text { water microbiota strongly influence gut microbiota at early } \\
\text { life stages. }\end{array}$ & $\begin{array}{l}\text { Bledsoe et al., } \\
2016\end{array}$ \\
\hline \multirow[t]{4}{*}{ Diet } & $\begin{array}{l}\text { Gut microbial diversity decreases as the source of nutrient } \\
\text { derivation in the diet are restricted. }\end{array}$ & Michl et al., 2017 \\
\hline & $\begin{array}{l}\text { Gut microbiome composition as well as metabolite profiles } \\
\text { are significantly altered by host species and feeding } \\
\text { behaviour. }\end{array}$ & Li et al., 2017a \\
\hline & $\begin{array}{l}\text { Colonisation with significantly different adherent and non- } \\
\text { adherent communities; non-adherent microbiome are } \\
\text { much diverse and diet-dependent than adherent } \\
\text { microbiome. }\end{array}$ & $\begin{array}{l}\text { Gajardo et al., } \\
2017\end{array}$ \\
\hline & $\begin{array}{l}\text { Gut microbiome differs by diet treatment but communities } \\
\text { in biofilters remain stable independent of diet; gut } \\
\text { communities less diverse than those of water and biofilters. }\end{array}$ & $\begin{array}{l}\text { Schmidt et al., } \\
2016\end{array}$ \\
\hline \multirow[t]{5}{*}{ Environment } & $\begin{array}{l}\text { Gut microbial diversity increases as the fish develop and } \\
\text { is less affected by the surrounding environment than by } \\
\text { host diet and development. }\end{array}$ & Li et al., 2017b \\
\hline & $\begin{array}{l}\text { Gut environment and other host development processes } \\
\text { shape the microbiome. }\end{array}$ & Yan et al., 2016 \\
\hline & $\begin{array}{l}\text { Water microbial communities strongly shape those in the } \\
\text { gut thereby resulting in a correlation between water and } \\
\text { gut microbial community dynamics. }\end{array}$ & Giatsis et al., 2015 \\
\hline & $\begin{array}{l}\text { Environmental factors more strongly influence microbiome } \\
\text { at early life stages. }\end{array}$ & $\begin{array}{l}\text { Stephens et al., } \\
2016\end{array}$ \\
\hline & $\begin{array}{l}\text { The microbiome is significantly altered even at a low level } \\
\text { of environmental changes but has strong resilience power. }\end{array}$ & $\begin{array}{l}\text { Narrowe et al., } \\
2015\end{array}$ \\
\hline \multirow[t]{2}{*}{ Host factors } & $\begin{array}{l}\text { Presence of core gut microbial flora regardless of the habitat } \\
\text { type will indicate the operational host selective forces. }\end{array}$ & Dehler et al., 2017 \\
\hline & $\begin{array}{l}\text { Similar gut microbiota regardless of source; shaped by host } \\
\text { factors; differences in composition highlight the habitat- } \\
\text { specific taxa. }\end{array}$ & Lyons et al., 2017 \\
\hline
\end{tabular}


Cont. Table 3.

\begin{tabular}{lll}
\hline Factors & \multicolumn{1}{c}{ Findings } & Reference \\
\hline & $\begin{array}{l}\text { Gut microbial communities in different species are not } \\
\text { exactly the same but also not different altogether. }\end{array}$ & Song et al., 2016 \\
\hline External factors & $\begin{array}{l}\text { Probiotic administration for a short period significantly } \\
\text { affects the gut microbiota composition at later stages of life. }\end{array}$ & Giatsis et al., 2016 \\
\cline { 2 - 3 } & $\begin{array}{l}\text { Diet, time of sampling and host-specific factors also } \\
\text { influence the microbes. }\end{array}$ & Zarkasi et al., \\
& $\begin{array}{l}\text { The gut microbiome is dependent upon the host life history } \\
\text { or genetic background; different nutritional stresses affect }\end{array}$ & Gatesoupe et al., \\
& host-microbiome and health differently. & \\
\hline Host factors & $\begin{array}{l}\text { Trophic level strongly influences the microbiome } \\
\text { composition of fish from the same habitats supported by }\end{array}$ & Liu et al., 2016 \\
& evidence of a large core gut microbiota in multiple species. & \\
\hline Trophic levels & $\begin{array}{l}\text { Geographical distance has less impact on gut microbiome; } \\
\text { diversity and identity of microbial communities are more }\end{array}$ & Llewellyn et al., \\
& strongly determined by life-cycle stage. & \\
\hline
\end{tabular}

\section{Methods for manipulation of gut microbiota}

The methods of manipulation of gut microbiota in fish include the alteration of dietary proteins and lipids, as well as the addition of probiotics and prebiotics in the diet.

Proteins: The source of proteins (Desai et al., 2012), their quantity (Geurden et al., 2014) and chemical structure (Kotzamanis et al., 2007) of proteins can influence the gut microbial composition. Peptides and glycopeptides, released through protein digestion can modulate the condition and activity of the intestinal cells as well as the microbiota of the gut (Świa tecka et al., 2012). Short peptides can be added to the diet that can directly manipulate gut microbial composition by providing suitable substrates for bacteria thus encouraging their proliferation (Kotzamanis et al., 2007). Some peptides produce antimicrobial activity and help to protect against pathogenic bacteria (Sila et al., 2014).

Lipids: It has been confirmed that the increased lipid concentrations resulted in a more diverse gut microbial community in fish (Ring $\varnothing$ and Birkbeck, 1999). The studies of Lødemel et al. (2001) have shown that the use of plant oils can improve fish's resistance to pathogenic bacteria as these natural plant oils are deficient in marine polyunsaturated fatty acids, arachidonic acid, eicosapentaenoic acid and docosahexaenoic acid.

Probiotics: Probiotics are live beneficial microorganisms which when administered in adequate amounts confer various health benefits on the host. Several studies have confirmed that the gut microbial communities can be manipulated with the application of probiotics (Asaduzzaman et al., 2018; Siriyappagouder et al., 2018).

Prebiotics: The term "dietary prebiotics", was defined as "a selectively fermented ingredient, that results in specific changes in the composition and/ or activity of the gastrointestinal microbiota, thus conferring benefit(s) upon host health" (Gibson et al., 2010). Galactooligosaccharides, arabinoxylooligosaccharides, fructooligosaccharides, chitooligosaccharide, mannanoligosacch-arides, inulin, and levan were the common prebiotics used in aquaculture (Ring $\varnothing$ et al., 2014).

\section{Conclusion}

The research findings on the gut microbiome of the fish, thus, far as provided an understanding 
on the gut microbial communities of various freshwater and marine fish, mechanisms in the development of the fish gut microbiota, the variation in their composition to the different environmental conditions of the water, diet, seasons, and trophic levels. This knowledge will pave way for the exploration of gut microbial

\section{REFERENCES}

Asaduzzaman M, Sofia E, Shakil A, Haque NF, Khan MNA et al., 2018. Host gut-derived probiotic bacteria promote hypertrophic muscle progression and up regulate growth-related gene expression of slow-growing Malaysian Mahseer Tortambroides. Aquacult Rep, 9: 37-45, doi: 10.1016/ j.aqrep.2017.12.001

Austin B, 2002. The bacterial microflora of fish. The Sci World J, 2: 558-572, doi: 10.1100/ tsw.2002.137

Banerjee S and Ghosh K, 2014. Enumeration of gut associated extracellular enzyme-producing yeasts in some freshwater fishes. J Appl Ichthyol, 30(5): 986-993, doi: 10.1111/jai.12457

Bano N, DeRae Smith A, Bennett W, Vasquez L and Hollibaugh JT, 2007. Dominance of mycoplasma in the guts of the Long-Jawed Mudsucker, Gillichthys mirabilis, from five California salt marshes. Environ Microbiol, 9(10): 2636-2641, doi: 10.1111/j.1462-2920.2007.01381.x

Bindiya ES, Tina KJ, Raghul SS and Bhat SG, 2015. Characterization of deep sea fish gut bacteria with antagonistic potential from Centroscyllium fabricii (Deep Sea Shark). Probiotics Antimicrob Proteins, 7(2): 157-163, doi: 10.1007/s12602-0159190-x

Bledsoe JW, Peterson BC, Swanson KS and Small BC, 2016. Ontogenetic characterization of the intestinal microbiota of channel catfish through 16S rRNA gene sequencing reveals insights on temporal shifts and the influence of environmental microbes. PLoS One, 11(11): e0166379, doi: 10.1371/ journal.pone.0166379

Burokas A, Moloney RD, Dinan TG and Cryan JF, 2015. Microbiota regulation of the mammalian gut-brain axis. Adv Appl Microbiol, 91: 1-62, doi: 10.1016/ bs.aambs.2015.02.001

Cahill MM, 1990. Bacterial flora of fishes: A manipulation techniques for increasing production, finding new advanced techniques to study the microbial communities that are normally difficult to culture or identification.

Conflict of interest: The authors declare that there is no conflict of interest.

review. Microb Ecol, 19(1): 21-41, doi: 10.1007/ BF02015051

Chen WY, Ng TH, Wu JH, Chen JW and Wang HC, 2017. Microbiome dynamics in a shrimp grow-out pond with possible outbreak of acute hepatopancreatic necrosis disease. Sci Rep, 7(1): 9395, doi: 10.1038/s41598-017-09923-6

Deb S, Das L and Das SK, 2020. Composition and functional characterization of the gut microbiome of freshwater pufferfish (Tetraodon cutcutia). Arch Microbiol, 202(10): 2761-2770, doi: 10.1007/ s00203-020-01997-7

Dehler CE, Secombes CJ and Martin AM, 2017. Seawater transfer alters the intestinal microbiota profiles of Atlantic salmon (Salmo salar L.). Sci Rep, 7(1): 13877, doi: 10.1038/s41598-017-13249-8

Desai AR, Links MG, Collins SA, Mansfield GS, Drew MD et al., 2012. Effects of plant-based diets on the distal gut microbiome of rainbow trout (Oncorhynchus mykiss). Aquaculture, 350: 134142, doi: 10.1016/j.aquaculture.2012.04.005

Egerton S, Culloty S, Whooley J, Stanton C and Ross RP, 2018. The gut microbiota of marine fish. Front Microbiol, 9: 873, doi: 10.3389/fmicb.2018.00873

FAO 2020. Fisheries and Aquaculture topics. Fact Sheets. Text by Jean- Francois Pulvenis. In: FAO Fisheries Division [online], Rome. The State of World Fisheries and Aquaculture (SOFIA), http:// www.fao.org/fishery/ [17 Sept 2020]

Gajardo K, Jaramillo-Torres A, Kortner TM, Merrifield DL, Tinsley J et al., 2017. Alternative protein sources in the diet modulate microbiota and functionality in the distal intestine of Atlantic salmon (Salmo salar). Appl Environ Microbiol, 83(5): e02615-16, doi: 10.1128/ AEM.02615-16

Gallagher ML, Luczkovich JJ and Stellwag EJ, 2001. 
Characterization of the ultrastructure of the gastrointestinal tract mucosa, stomach contents and liver enzyme activity of the pinfish during development. J Fish Biol, 58(6): 1704-1713, doi: 10.1111/j.1095-8649.2001.tb02324.x

Gatesoupe FJ, Huelva C, Le Bayon N, Le Delliou H, Madec L et al., 2016. The highly variable microbiota associated to intestinal mucosa correlates with growth and hypoxia resistance of sea bass, Dicentrarchus labrax, submitted to different nutritional histories. BMC Microbiol, 16(1): 266, doi: 10.1186/s12866-016-0885-2

German DP, Nagle BC, Villeda JM, Ruiz AM, Thomso AW et al., 2010. Evolution of herbivory in a carnivorous clade of minnows (Teleostei: Cyprinidae): effects on gut size and digestive physiology. Physiol Biochem Zool, 83(1): 1-18, doi: $10.1086 / 648510$

Geurden I, Mennigen J, Plagnes-Juan E, Veron V, Cerezo T et al., 2014. High or low dietary carbohydrate: protein ratios during first-feeding affect glucose metabolism and intestinal microbiota in juvenile rainbow trout. J Exp Biol, 217(19): 3396-3406, doi: 10.1242/jeb. 106062

Giatsis C, Sipkema D, Smidt H, Heilig H, Benvenuti G et al., 2015. The impact of rearing environment on the development of gut microbiota in tilapia larvae. Sci Rep, 5(1): 18206, doi: 10.1038/srep18206

Giatsis C, Sipkema D, Ramiro-Garcia J, Bacanu GM, Abernathy $\mathrm{J}$ et al., 2016. Probiotic legacy effects on gut microbial assembly in tilapia larvae. Sci Rep, 6: 33965, doi: 10.1038/srep33965

Gibbons NE, 1933. The slime and intestinal flora of some marine fishes. Contrib Can Biol Fish, 8(1): 275-290, doi: 10.1139/f33-022

Gibson GR, Scott KP, Rastall RA, Tuohy KM, Hotchkiss A et al., 2010. Dietary prebiotics: current status and new definition. Food Sci Technol Bull Funct Foods, 7(1): 1-19, doi: 10.1616/1476-2137.15880

Gilmour A, McCallum MF and Allan MC, 1976. The bacteriology of power station effluent used to farm marine fish. Aquaculture, 7(4): 357-362, doi: 10.1016/0044-8486(76)90132-0

Givens CE, Ransom B, Bano N and Hollibaugh JT, 2015. Comparison of the gut microbiomes of 12 bony fish and 3 shark species. Mar Ecol Prog Ser, 518: 209-223, doi: 10.3354/meps11034
Gómez GD and Balcázar JL, 2008. A review on the interactions between gut microbiota and innate immunity of fish. FEMS Immunol Med Microbiol, 52(2): 145-154, doi: 10.1111/j.1574695X.2007.00343.X

Grimes DJ, Brayton P, Colwell RR and Gruber SH, 1985. Vibrios as autochthonous flora of neritic sharks. Syst Appl Microbiol, 6(2): 221-226, doi: 10.1016/S0723-2020(85)80056-4

Hagi T, Tanaka D, Iwamura Y and Hoshino T, 2004. Diversity and seasonal changes in lactic acid bacteria in the intestinal tract of cultured freshwater fish. Aquaculture, 234(1-4): 335-346, doi: 10.1016/j. aquaculture.2004.01.018

Hansen GH and Olafsen JA, 1999. Bacterial interactions in early life stages of marine cold water fish. Microb Ecol, 38(1): 1-26, doi: 10.1007/s002489900158

Holt CC, Bass D, Stentiford GD and van der Giezen M, 2020. Understanding the role of the shrimp gut microbiome in health and disease. J Invertebr Pathol: 107387, doi: 10.1016/j.jip.2020.107387

Izvekova GI, Izvekov EI and Plotnikov AO, 2007. Symbiotic microflora in fishes of different ecological groups. Biol Bull, 34(6): 610-618, doi: 10.1134/S106235900706012X

Jami M, Ghanbari M, Kneifel W and Domig KJ, 2015. Phylogenetic diversity and biological activity of culturable Actinobacteria isolated from freshwater fish gut microbiota. Microbiol Res, 175: 6-15, doi: 10.1016/j.micres.2015.01.009

Jayasree L, Janakiram P and Madhavi R, 2006. Characterization of Vibrio spp. associated with diseased shrimp from culture ponds of Andhra Pradesh (India). J World Aquacult Soc, 37(4): 523532, doi: 10.1111/j.1749-7345.2006.00066.x

Kim DH, Brunt J and Austin B, 2007. Microbial diversity of intestinal contents and mucus in rainbow trout (Oncorhynchus mykiss). J Appl Microbiol, 102(6): 1654-1664, doi: $10.1111 / \mathrm{j} .1365-$ 2672.2006.03185.x

Kotzamanis YP, Gisbert E, Gatesoupe FJ, Infante JZ and Cahu C, 2007. Effects of different dietary levels of fish protein hydrolysates on growth, digestive enzymes, gut microbiota, and resistance to Vibrio anguillarum in European sea bass (Dicentrarchus labrax) larvae. Comp Biochem Physiol A Mol Integr Physiol, 147(1): 205-214, doi: 10.1016/ j.cbpa.2006.12.037 
Larsen AM, Mohammed HH and Arias CR, 2014. Characterization of the gut microbiota of three commercially valuable warmwater fish species. J Appl Microbiol, 116(6): 1396-1404, doi: 10.1111/jam.12475

Lauzon HL, Gudmundsdottir S, Petursdottir SK, Reynisson E, Steinarsson A et al., 2010. Microbiota of Atlantic cod (Gadus morhua L.) rearing systems at pre- and post-hatch stages and the effect of different treatments. J Appl Microbiol, 109(5): 1775-1789, doi: 10.1111/j.13652672.2010.04806.x

Li T, Long M, Li H, Gatesoupe FJ, Zhang X et al., 2017a. Multi-omics analysis reveals a correlation between the host phylogeny, gut microbiota and metabolite profiles in cyprinid fishes. Front Microbiol, 8: 454, doi: 10.3389/fmicb. 2017.00454

Li X, Zhou L, Yu Y, Ni J, Xu W et al., $2017 \mathrm{~b}$. Composition of gut microbiota in the gibel carp (Carassius auratus gibelio) varies with host development. Microb Ecol, 74(1): 239-249, doi: 10.1007/s00248-016-0924-4

Liu H, Guo X, Gooneratne R, Lai R, Zeng C et al., 2016. The gut microbiome and degradation enzyme activity of wild freshwater fishes influenced by their trophic levels. Sci Rep, 6: 24340, doi: $10.1038 /$ srep24340

Llewellyn MS, Boutin S, Hoseinifar SH and Derome N, 2014. Teleost microbiomes: the state of the art in their characterization, manipulation and importance in aquaculture and fisheries. Front Microbiol, 5: 207, doi: 10.3389/ fmicb.2014.00207

Llewellyn MS, McGinnity P, Dionne M, Letourneau J, Thonier F et al., 2016. The biogeography of the Atlantic salmon (Salmo salar) gut microbiome. ISME J, 10(5): 1280-1284, doi: 10.1038/ismej.2015.189

Lødemel JB, Mayhew TM, Myklebust R, Olsen RE, Espelid S et al., 2001. Effect of three dietary oils on disease susceptibility in Arctic charr (Salvelinus alpinus L.) during cohabitant challenge with Aeromonas salmonicida ssp. salmonicida. Aquacult Res, 32(12): 935-945, doi: 10.1046/j.1365-2109.2001.00621.x

Lyons PP, Turnbull JF, Dawson KA and Crumlish M, 2017. Phylogenetic and functional characterization of the distal intestinal microbiome of rainbow trout Oncorhynchus mykiss from both farm and aquarium settings. J Appl Microbiol, 122(2): 347-363, doi: $10.1111 /$ jam. 13347

Macfarlane GT and Englyst HN, 1986. Starch utilization by the human large intestinal microflora. J Appl Bacteriol, 60(3): 195-201, doi: 10.1111/j.13652672.1986.tb01073.x

Mandal S and Ghosh K, 2013. Isolation of tannaseproducing microbiota from the gastrointestinal tracts of some freshwater fish. J Appl Ichthyol, 29(1): 145-153, doi: 10.1111/j.14390426.2012.02054.x

Margolis L, 1953. The effect of fasting on the bacterial flora of the intestine of fish. J Fish Res Board Can, 10(2): 62-63, doi: 10.1139/f53-003

McCormick SD, Sheehan TF, Björnsson BT, Lipsky C, Kocik JF et al., 2013. Physiological and endocrine changes in Atlantic salmon smolts during hatchery rearing, downstream migration, and ocean entry. Can J Fish Aquat Sci, 70(1): 105-118, doi: 10.1139/cjfas-2012-0151

Michl SC, Ratten JM, Beyer M, Hasler M, LaRoche J et al., 2017. The malleable gut microbiome of juvenile rainbow trout (Oncorhynchus mykiss): dietdependent shifts of bacterial community structures. PloS One, 12(5): e0177735, doi: 10.1371/journal.pone.0177735

Milanez GD, Masangkay FR, Thomas RC, Ordona MOGO, Bernales GQ et al., 2017. Molecular identification of Vermamoeba vermiformis from freshwater fish in lake Taal, Philippines. Exp Parasitol, 183: 201-206, doi: 10.1016/ j.exppara.2017.09.009

Narrowe AB, Albuthi-Lantz M, Smith EP, Bower KJ, Roane TM et al., 2015. Perturbation and restoration of the fathead minnow gut microbiome after lowlevel triclosan exposure. Microbiome, 3(1): 6, doi: 10.1186/s40168-015-0069-6

Nayak SK, 2010. Role of gastrointestinal microbiota in fish. Aquacult Res, 41(11): 1553-1573, doi: 10.1111/j.1365-2109.2010.02546.x

Nielsen S, Walburn JW, Verges A, Thomas T and Egan S, 2017. Microbiome patterns across the gastrointestinal tract of the rabbitfish Siganus fuscescens. Peer J, 5: e3317, doi: 10.7717/ peerj. 3317 
Nikouli E, Meziti A, Smeti E, Antonopoulou E, Mente E et al., 2020. Gut microbiota of five sympatrically farmed marine fish species in the Aegean Sea. Microb Ecol, PMID: 32840670, doi: 10.1007/ s00248-020-01580-z

Orlov AV, Gerasimov YV and Lapshin OM, 2006. The feeding behaviour of cultured and wild Atlantic salmon, Salmo salar L., in the Louvenga River, Kola Peninsula, Russia. ICES J Mar Sci, 63(7): 1297-1303, doi: 10.1016/j.icesjms.2006.05.004

Parris DJ, Brooker RM, Morgan MA, Dixson DL and Stewart FJ, 2016. Whole gut microbiome composition of damselfish and cardinalfish before and after reef settlement. Peer J, 4: e2412, doi: $10.7717 /$ peerj. 2412

Rai AK, Jini R, Swapna HC, Sachindra NM, Bhaskar N et al., 2011. Application of native lactic acid bacteria (LAB) for fermentative recovery of lipids and proteins from fish processing wastes: bioactivities of fermentation products. J Aquat Food Prod Technol, 20(1): 32-44, doi: 10.1080/ 10498850.2010.528174

Reed GB and Spence CM, 1929. The intestinal and slime flora of the haddock: a preliminary report. Contrib Can Biol Fish, 4(1): 257-264, doi: 10.1139/f 29-019

Reveco FE, Øverland M, Romarheim OH and Mydland LT, 2014. Intestinal bacterial community structure differs between healthy and inflamed intestines in Atlantic salmon (Salmo salar L.). Aquaculture, 420: 262-269, doi: 10.1016/ j.aquaculture.2013.11.007

Ring $\varnothing \mathrm{E}$ and Birkbeck TH, 1999. Intestinal microflora of fish and fry: a review. Aquacult Res, 30(2): 73-93

Ring $\varnothing \mathrm{E}$, Olsen RE, Mayhew TM and Myklebust R, 2003. Electron microscopy of the intestinal microflora of fish. Aquaculture, 227(1-4): 395-415, doi: 10.1016/j.aquaculture.2003.05.001

Ring $\varnothing$ E, Dimitroglou A, Hoseinifar SH and Davies SJ, 2014. Prebiotics in finfish: an update. In: Aquaculture nutrition: Gut Health, Probiotics and Prebiotics, Merrifield DL, Ringo E (edn.), Wiley, pp360-400

Roeselers G, Mittge EK, Stephens WZ, Parichy DM, Cavanaugh CM et al., 2011. Evidence for a core gut microbiota in the zebrafish. ISME J, 5(10): 1595-1608, doi: 10.1038/ismej.2011.38
Romero J and Navarrete P, 2006. 16S rDNA-based analysis of dominant bacterial populations associated with early life stages of coho salmon (Oncorhynchus kisutch). Microb Ecol, 51(4): 422430, doi: 10.1007/s00248-006-9037-9

Rungrassamee W, Klanchui A, Maibunkaew S, Chaiyapechara S, Jiravanichpaisal P et al., 2014. Characterization of intestinal bacteria in wild and domesticated adult black tiger shrimp (Penaeus monodon). PloS One, 9(3): e91853, doi: 10.1371/ journal.pone.0091853

Rungrassamee W, Klanchui A, Maibunkaew S and Karoonuthaisiri N, 2016. Bacterial dynamics in intestines of the black tiger shrimp and the Pacific white shrimp during Vibrio harveyi exposure. J Invertebr Pathol, 133: 12-19, doi: 10.1016/ j.jip.2015.11.004

Sakata T, Sugita H, Mitsuoka T, Kakimoto D and Kadota $\mathrm{H}, 1980$. Isolation and distribution of obligate anaerobic bacteria from the intestines of freshwater fish. Bull Jap Soc Sci Fish, 46(10): 1249-1255, doi: 10.2331/suisan.46.1249

Sandrini S, Aldriwesh M, Alruways M and Freestone P, 2015. Microbial endocrinology: host-bacteria communication within the gut microbiome. J Endocrinol, 225(2): R21-R34, doi: 10.1530/JOE14-0615

Schmidt VT, Smith KF, Melvin DW and Amaral-Zettler LA, 2015. Community assembly of a euryhaline fish microbiome during salinity acclimation. Mol Ecol, 24(10): 2537-2550, doi: 10.1111/mec.13177

Schmidt V, Amaral-Zettler L, Davidson J, Summerfelt S and Good C, 2016. Influence of fishmeal-free diets on microbial communities in Atlantic salmon (Salmo salar) recirculation aquaculture systems. Appl Environ Microbiol, 82(15): 4470-4481, doi: 10.1128/AEM.00902-16

Sequeiros C, Garcés ME, Vallejo M, Marguet ER and Olivera NL, 2015. Potential aquaculture probiont Lactococcus lactis TW34 produces nisin Z and inhibits the fish pathogen Lactococcus garvieae. Arch Microbiol, 197(3): 449-458, doi: 10.1007/s00203-014-1076-X

Sera H, Ishida Y and Kadota H, 1972. Bacterial-flora in digestive tracts of marine fish-IV. Effect of $\mathrm{H}^{+}$ concentration and gastric juices on indigenous bacteria. Bull Jap Soc Sci Fish, 38(8): 859-863 
Sila A, Nedjar-Arroume N, Hedhili K, Chataigné G, Balti $\mathrm{R}$ et al., 2014. Antibacterial peptides from barbel muscle protein hydrolysates: activity against some pathogenic bacteria. LWT-Food Sci Technol, 55(1): 183-188, doi: 10.1016/j.lwt.2013.07.021

Siriyappagouder P, Galindo-Villegas J, Lokesh J, Mulero V, Fernandes JMO et al., 2018. Exposure to yeast shapes the intestinal bacterial community assembly in zebrafish larvae. Front Microbiol, 9: 1868, doi: 10.3389/fmicb.2018.01868

Song W, Li L, Huang H, Jiang K, Zhang F et al., 2016. The gut microbial community of antarctic fish detected by $16 \mathrm{~S}$ rRNA gene sequence analysis. BioMed Res Int, 2016: 3241529, doi: 10.1155/2016/3241529

Stackebrandt E, Murray RGE and Trüper HG, 1988. Proteobacteria classis nov., a name for the phylogenetic taxon that includes the "purple bacteria and their relatives". Int J Syst Microbiol, 38(3): 321-325, doi: 10.1099/ 00207713-38-3-321

Stephens WZ, Burns AR, Stagaman K, Won S, Rawls JF et al., 2016. The composition of the zebrafish intestinal microbial community varies across development. ISME J, 10(3): 644-654, doi: 10.1038/ismej.2015.140

Sugita H, Miyajima C and Deguchi Y, 1991. The vitamin B12-producing ability of the intestinal microflora of freshwater fish. Aquaculture, 92: 267-276, doi: 10.1016/0044-8486(91)90028-6

Sugita H, Kawasaki J and Deguchi Y, 1997. Production of amylase by the intestinal microflora in cultured freshwater fish. Lett Appl Microbiol, 24(2): 105108, doi: 10.1046/j.1472-765X.1997.00360.x

Sugita $\mathrm{H}$ and Ito Y, 2006. Identification of intestlinal bacteria from Japanese flounder (Paralichthys olivaceus) and their ability to digest chitin. Lett Appl Microbiol, 43(3): 336-342, doi: 10.1111/ j.1472-765X.2006.01943.X

Świą tecka D, Markiewicz LH and Wróblewska B, 2012. Experimental immunology pea protein hydrolysate as a factor modulating the adhesion of bacteria to enterocytes, epithelial proliferation and cytokine secretion-an in vitro study. Cen Eur J Immunol, 37(3): 227-231, doi: 10.5114/ ceji.2012.30798
Talwar C, Nagar S, Lal R and Negi RK, 2018. Fish gut microbiome: current approaches and future perspectives. Indian J Microbiol, 58(4): 397-414, doi: 10.1007/s12088-018-0760-y

Tarnecki AM, Burgos FA, Ray CL and Arias CR, 2017. Fish intestinal microbiome: diversity and symbiosis unravelled by metagenomics. J Appl Microbiol, 123(1): 2-17, doi: 10.1111/jam.13415

Teplitski M, Wright AC and Lorca G, 2009. Biological approaches for controlling shellfish-associated pathogens. Curr Opin Biotech, 20(2): 185-190, doi: 10.1016/j.copbio.2009.03.001

Titus E and Ahearn GA, 1992. Vertebrate gastrointestinal fermentation: transport mechanisms for volatile fatty acids. Am J Physiol Regul Integr Comp Physiol, 262(4 Pt 2): R547-R553, doi: 10.1152/ ajpregu.1992.262.4.R547

Tran NT, Zhang J, Xiong F, Wang GT, Li WX et al., 2018. Altered gut microbiota associated with intestinal disease in grass carp (Ctenopharyngodon idellus). World J Microbiol Biotechnol, 34(6): 71, doi: 10.1007/s11274-018-2447-2

Tsuchiya C, Sakata T and Sugita H, 2008. Novel ecological niche of Cetobacterium somerae, an anaerobic bacterium in the intestinal tracts of freshwater fish. Lett Appl Microbiol, 46(1): 43-48, doi: 10.1111/j.1472-765X.2007.02258.x

Uchii K, Matsui K, Yonekura R, Tani K, Kenzaka T et al., 2006. Genetic and physiological characterization of the intestinal bacterial microbiota of bluegill (Lepomis macrochirus) with three different feeding habits. Microb Ecol, 51(3): 277-284, doi: 10.1007/s00248-006-9018-z

Verschuere L, Rombaut G, Sorgeloos P and Verstraete W, 2000. Probiotic bacteria as biological control agents in aquaculture. Microbiol Mol Biol Rev, 64(4): 655-671, doi: 10.1128/mmbr. 64.4.655-671.2000

Walter JM, Bagi A and Pampanin DM, 2019. Insights into the potential of the Atlantic cod gut microbiome as biomarker of oil contamination in the marine environment. Microorganisms, 7(7): 209, doi: 10.3390/microorganisms 7070209

Wang AR, Ran C, Ring $\varnothing E$ and Zhou ZG, 2018. Progress in fish gastrointestinal microbiota research. Rev Aquacult, 10(3): 626-640, doi: 10.1111/raq.12191 
White WL, Coveny AH, Robertson J and Clements KD, 2010. Utilisation of mannitol by temperate marine herbivorous fishes. J Exp Mar Biol Ecol, 391(12): 50-56, doi: 10.1016/j.jembe.2010.06.007

Willmott ME, Clements KD and Wells RMG, 2005. The influence of diet and gastrointestinal fermentation on key enzymes of substrate utilization in marine teleost fishes. J Exp Mar Biol Ecol, 317(1): 97-108, doi: $10.1016 /$ j.jembe.2004.11.008

Xia JH, Lin G, Fu GH, Wan ZY, Lee Met al., 2014. The intestinal microbiome of fish under starvation. BMC Genomics, 15: 266, doi: 10.1186/1471-2164-15-266

Xiong JB, Nie L and Chen J, 2019. Current understanding on the roles of gut microbiota in fish disease and immunity. Zool Res, 40(2): 70, doi: $10.24272 /$ j.issn.2095-8137.2018.069
Yan Q, Li J, Yu Y, Wang J, He Z et al., 2016. Environmental filtering decreases with fish development for the assembly of gut microbiota. Environ Microbiol, 18(12): 4739-4754, doi: $10.1111 / 1462-2920.13365$

Zarkasi KZ, Taylor RS, Abell GC, Tamplin ML, Glencross BD et al., 2016. Atlantic salmon (Salmo salar L.) gastrointestinal microbial community dynamics in relation to digesta properties and diet. Microb Ecol, 71(3): 589-603, doi: 10.1007/ s00248-015-0728-y

Zoqratt MZHM, Eng WWH, Thai BT, Austin CM and Gan HM, 2018. Microbiome analysis of Pacific white shrimp gut and rearing water from Malaysia and Vietnam: implications for aquaculture research and management. PeerJ, 6: e5826, doi: 10.7717/ peerj. 5826 